\title{
BMPR2 Gene
}

National Cancer Institute

\section{Source}

National Cancer Institute. BMPR2 Gene. NCI Thesaurus. Code C21368.

This gene is involved in receptor mediated ligand-induced signal transduction that is

critical for endochondral bone formation and embryogenesis. 